Research Report No. 17/2009

\title{
Intellectual Property Right Regimes, Firms and the Commodification of Knowledge
}

Benjamin Coriat

Olivier Weinstein

Follow this and additional works at: http://digitalcommons.osgoode.yorku.ca/clpe

\section{Recommended Citation}

Coriat, Benjamin and Weinstein, Olivier, "Intellectual Property Right Regimes, Firms and the Commodification of Knowledge" (2009). Comparative Research in Law \& Political Economy. Research Paper No. 17/2009.

http://digitalcommons.osgoode.yorku.ca/clpe/130 


\section{Comparative Research in Law \& Political Economy}

CLPE RESEARCH PAPER $17 / 2009$

\section{Benjamin Coriat and Olivier Weinstein}

\section{Intellectual Property Right Regimes, Firms, and the Commodification of Knowledge}

EDITORS: Peer Zumbansen (Osgoode Hall Law School, Toronto, Director, Comparative Research in Law and Political Economy, York University), John W. Cioffi (University of California at Riverside), Nassim Nasser (Osgoode Hall Law School, Toronto, Production Editor) 

CLPE Research Paper 17/2009

Vol. 05 No. 03 (2009)

Benjamin Coriat and Olivier Weinstein

\title{
Intellectual Property Right Regimes, Firms and the Commodification OF KNOWLEDGE
}

\begin{abstract}
The aim of this paper is to analyse the evolution of the intellectual property regime, and more precisely the patent regime, in the USA, since the $19^{\text {th }}$ century. To do so, we shall consider intellectual property within the context of general transformations in capitalism, focusing on two main historical phases. Firstly, the period covering the formation and development of "corporate capitalism" dominated by large corporations. And then the new phase, which opened up in the 1980s, marked by the rise to power of finance. From a perspective of institutional complementarities, we seek to show how the characteristics and implications of IPR regimes can only be understood in relation to transformations in the main institutional forms of capitalism: forms of the firm, the status of labour (the "wage-labour nexus"), and market forms.
\end{abstract}

Keywords: intellectual property, patent, knowledge, corporate capitalism, firm, market, financiarisation, institutional complementarities.

JEL classification: O34 - Intellectual Property Rights, P1 - Capitalist Systems

Benjamin Coriat

Professor in Economics

University Paris 13

99 av. J.B. Clément 93430 Villetaneuse, France

coriat@club-internet.fr

Olivier Weinstein

Professor in Economics

University Paris 13

99 av. J.B. Clément 93430 Villetaneuse, France

weinstein@univ-paris13.fr 


\title{
InTEllectual Property Right Regimes, Firms AND THE COMMODIFICATION OF KNOWLEDGE
}

\author{
Benjamin Coriat and Olivier Weinstein *
}

\section{INTRODUCTION}

Describing our economies as "knowledge-based" is now a commonplace. This paper does not set out to examine the precise content or pertinence of this view of modern capitalism. Let us simply observe that the importance of knowledge - and more specifically of scientific and technological knowledge - is an essential dimension of industrial development, and has been for a long time. It has been one of the distinctive features for nearly two centuries, at least, as numerous authors, like Kutznets (1966), have pointed out.

In this context, saying that an economy is "knowledge-based" does not mean that economic activity uses "more" knowledge than it did before. Rather, we believe it means that the conditions of production and use of knowledge, in its different forms, is being transformed: knowledge has become an economic good which, under changed conditions, can circulate as such; in Winter's words (1987), it has become a "strategic asset". The question then arises of the conditions under which economic agents can control and appropriate knowledge, and turn it into a revenue source. The answer to this question must be sought in an analysis of the legal and institutional framework governing the conditions of production, circulation and use of knowledge. And intellectual property systems lie at the centre of this framework.

The unprecedented development of intellectual property has been one of the most important elements in the transformation of capitalist economies over the last twenty years. The major changes in the intellectual property regime in the United States and the world-wide TRIPS (Trade-Related Aspects of Intellectual Property Rights) agreement, signed in 1994 under the aegis of the World Trade Organisation, bear witness to this. We shall adopt a historical perspective here, as a means of grasping the significance and scale of these transformations: our aim is to analyse the evolution of the intellectual property regime, and more precisely the patent regime, in the USA, since the $19^{\text {th }}$ century. To do so, we shall consider intellectual property within the context of general transformations in capitalism, focusing on two main historical

\footnotetext{
${ }^{\circ}$ The authors whish to thank the MSH Paris-Nord for its support to this research

* Olivier Weinstein is currently professor emeritus at the University Paris 13, and member of the CEPN (Centre d'Economie de Paris Nord), a research center associated to the CNRS. Is main research area are currently economics of innovation and economy of the firm, and the analysis of property and markets, with an institutionalist perspective.

Benjamin Coriat is a leading French economist of the firm and its economic organization and industrial development - http://www.univ-paris13.fr/CEPN/cepn.htm
} 
phases. Firstly, the period covering the formation and development of "corporate capitalism" dominated by large corporations, also be referred to as the "Fordist" period. And then the new phase, which opened up in the 1980s, marked by the rise to power of finance. From a perspective of institutional complementarities, we seek to show how the characteristics and implications of IPR regimes can only be understood in relation to transformations in the main institutional forms of capitalism, and more precisely forms of the firm, the status of labour (the "wage-labour nexus", following the terminology of the French Regulation School), and market forms (product markets and financial markets).

The paper is organised as follows: after briefly recalling the IPR regime established in the USA in the $19^{\text {th }}$ century during a "pre-Fordist" (or pre-corporate) phase, the two subsequent sections describe how corporate capitalism radically altered the nature of the patent system, and then how the 1980s, with the disintegration of Fordism and the rise of finance-led capitalism, in turn saw the transformation of intellectual property.

\section{PATENTS AND THE MARKET FOR TECHNOLOGY IN $19^{\mathrm{TH}}$ CENTURY USA: THE "PRE-FORDIST" REGIME}

To understand how the intellectual property regime of corporate capitalism formed in the $20^{\text {th }}$ century, it is worth starting by looking at the situation at the end of the $19^{\text {th }}$ century, in what can be described as the "pre-Fordist" phase. After a period marked by a powerful anti-patent movement, the advocates of the patent system finally won the day, in both Europe and the United States ${ }^{1}$. This resulted in the establishment of a "modern" system of patents in most countries ${ }^{2}$. In the United States, a profoundly new system grew up as early as the first half of the $19^{\text {th }}$ century, on the foundations of the 1936Patent Act. This deserves particular attention, as it was to form the basis for the formation of certain aspects of the new capitalism that emerged towards the end of the century.

If we focus on the patent system - and this is indeed where the central issues were to play themselves out, to do with the increasingly important role of invention and innovation in growth - we can pick out a number of major features (Noble, 1977; Khan and Sokoloff, 2001):

- The institution of low registration fees and an impersonal application procedure.

- The creation of an examination system, by trained experts, replacing the previous simple registration system (1836 Patent Act).

\footnotetext{
${ }^{1}$ See Machlup (1958), Penrose and Machlup (1950). The debate did, nevertheless, leave certain traces, notably around the question of compulsory licensing.

${ }^{2}$ Thus, major reforms were introduced in Great Britain in 1874, a unified patent system was created in Germany in 1872, Japan created its system in 1885 (after abolishing it in 1873), and Switzerland set up its system 1882, after two referenda. Holland was the last country to abandon the principle of free trade in inventions, only re-introducing a patent system in 1912 (Machlup, 1950).
} 
- The attribution of an exclusive property right ${ }^{3}$.

The legal system gradually defined a set of rules and principles protecting the rights of patentees and of those who purchased or licensed patented technologies (Khan, B. Zorina. 1995.). The federal courts were responsible for enforcing the new patent system.

One crucial dimension needs to be highlighted. Initially, the aim of this system was to favour individual inventive activity. The patentee had to be an individual. Only the individual inventor could receive a patent; firms could not receive patents directly for inventions developed inside the firm (Noble, 1977, Lamoreaux and Sokoloff, 1999). Until the end of the $19^{\text {th }}$ century, the firm had no automatic rights over patents registered by their employees ${ }^{4}$.

These reforms resulted in strong growth in the number of patents registered between 1840 and 1870, with most applications being made by individual inventors ${ }^{5}$. This movement was accompanied by the formation of what we can consider a veritable market for technology ${ }^{6}$. According to Lamoreaux and Sokoloff (2001), this market was based essentially on "arms-length transactions" "7 between individual inventors and firms. Between the two parties, specialist intermediaries, mainly lawyers and "patent agents", played an essential role in the formation of the market, a role that gradually grew from about 1840 onwards (Lamoreaux and Sokoloff, 2001, 2002). It was also during this period that the first "patent pools" were formed ${ }^{8}$, although this form only really became significant in the $20^{\text {th }}$ century, with the development of corporate capitalism. This configuration can be understood in terms of the corporate practices prevailing at

\footnotetext{
${ }^{3}$ Lowell v. Lewis (15 F. Cas. 1018 [1817]): "[T]he inventor has a property in his invention; a property which is often of very great value, and of which the law intended to give him the absolute enjoyment and possession . . . involving some of the dearest and most valuable rights which society acknowledges, and the constitution itself means to favor."
}

${ }^{4}$ The firm had no right over an employee's invention, even if the invention had been developed inside the firm, "in the absence of an express agreement" (Supreme Court, 1893). Contracts in which employees were required to assign their patents to the company were relatively rare (Lamoreaux and Sokoloff, 1999).

${ }^{5}$ According to some estimations, in 1885 only $12 \%$ of patents were issued to corporations (Noble, 1977).

${ }^{6}$ See Lamoreaux and Sokoloff, $(1999,2001,2002)$. The formation of the market appears to be evidenced by the high ratio of the number of assignments of contracts to the number of patents, which reached a maximum of 0.83 in 1870-1871(Khan and Sokoloff, 2004).

7 This observation, made by Lamoreaux and Sokoloff, (2001), seems to contradict the widely-held idea that uncertainty and asymmetries of information make such transactions very difficult to implement in the case of information or knowledge goods. It would certainly be useful to study more precisely the content of these transactions between firms and individual inventors, and the role played by the intermediaries.

${ }^{8}$ Such as, in 1856, a patent pool between manufacturers of sewing-machine parts (Noble, 1977: 87). 
the time: firms tended to acquire inventions from outside, rather than seeking to develop them "in-house". The behaviour of Bell represents an extreme example of this ${ }^{9}$.

The evolution of US capitalism steadily eroded this system. Firstly, early in the $20^{\text {th }}$ century, there appeared "a trend towards long-term attachments between highly productive inventors and particular firms" (Khan and Sokoloff, 2001), implying a form of relation quite different from the "standard" market one. This trend continued during the greatest part of the $20^{\text {th }}$ century. But the most important evolution involved the industrial structure: the move towards a system dominated by large corporations, where innovation is based mainly on in-house $R \& D$, and the decline of the individual inventor and the market for technology.

And this was to lead to a radical transformation in the nature of the intellectual property regime.

\section{RESEARCH, INNOVATION AND IPR IN THE ERA OF CORPORATE CAPITALISM}

\section{A. THE EMERGENCE OF CORPORATE CAPITALISM AND THE NEW MODES OF INNOVATION AND INVENTION}

To appreciate this transformation in the IPR regime, we must situate it within the context of the changes undergone by capitalism, from the end of the $19^{\text {th }}$ century, leading to the formation of corporate capitalism. These changes affected not only the structure of the industrial system, but also the conditions of production of technological and scientific knowledge on which the system depends. They contributed to what we can describe as a transition from a "Schumpeter mark I" to a "Schumpeter mark II" innovation regime: the shift, if we follow Schumpeter, from entrepreneurial capitalism to a form of capitalism dominated by large corporations.

The first major event was the emergence, in the centre of the capitalism system, of a new institutional form: the large corporation, which we could also call the "Chandlerian" firm, in homage to the author who gave the most masterly description and analysis of the structure and changes in the firm throughout the $20^{\text {th }}$ century. This firm is "the primary instrument in capitalist economies for the production and distribution of current goods and services and for the planning and allocation for future production and distribution" (Chandler, 1992). It is a complex institution, based on:

- A hierarchical structure and the centralisation of assets and activities inside large multi-unit entities.

- Centralised control, hierarchical and functional internal organisation, and vertical integration.

\footnotetext{
${ }^{9}$ See Noble (1977)
} 
- A specific mode of labour organisation and management (The "Faloyand-Taylorist heritage", Hatchuel, 2004), based on administrative control, with a high degree of integration of the workers inside the firm ${ }^{10}$.

This last aspect is particularly important. The high level of integration of employees within the firm is one of the chief characteristics of the industrial evolution. It went hand in hand with the construction of the wage-labour nexus. It required the creation and implementation of the legal and organisational instruments of a new system of labour control, and of the management of knowledge and skills within the firm. As we shall see, the development of the IPR regime was one component of this evolution, related to a trend towards the internalisation of the inventive activity.

The transformations of the firm are interlinked with a general process of institutionalisation and professionalization of innovation and R\&D (Noble, 1977; Mowery and Rosenberg, 1998). The production of knowledge is structured around two domains: on the one side companiesessentially large corporations - the central site for the production of technological knowledge and for inventive and innovative activity, and on the other side the predominantly public system of research - made up of universities and public research centres - where the scientific activity is concentrated. Indeed, the development of scientific institutions, and particularly of university systems, is the other major dimension of the transformations accompanying the rise of corporate capitalism. It is built on totally different institutional foundations to those underlying the corporate sphere: non-profit organisations orientated towards the production of freely-circulating public knowledge, and it is governed by its own specific rules. This system makes the rapid disclosure of knowledge, through publication or oral presentation, driven by a priority reward system and accompanied by practices of free cooperation and peer review, the behavioural norm for the scientific community. The priority reward system is long-established. It has governed the scientific community since the $18^{\text {th }}$ century (Merton, 1973), but it was substantially strengthened and systemised by the process of institutionalisation and professionalization of science.

So, it would be fair to say that the institutionalisation and professionalization of innovation and research in the $20^{\text {th }}$ century was initially based on a dual property regime, a combination of the "kingdom of technology" and the "republic of science" (Dasgupta and David, 1994). This dualism found expression, notably, in the delimitation of the field of activities covered by patenting: patents could be registered on inventions (i.e. technical devices) but not on knowledge, especially fundamental scientific knowledge.

Intellectual property, and the patent system in particular, must be examined within the context of these institutional transformations. Its development is closely linked to the growing importance

\footnotetext{
${ }^{10}$ Another essential dimension is the system of governance, related to the rise of managerial power. This aspect has been highlighted by the managerial theories of the firm. It is connected with the transformations of financial markets, as well as the internal development of managerial hierarchies (see Berle and Means, Galbraith), and based on a dominant legal form: the (public) corporation. This point will not be examined here.
} 
of the large corporation in the production and appropriation of productive skills and knowledge and in the inventive and innovative activity.

\section{B. THE EVOLUTION OF THE PATENT SYSTEM: FROM AN INDIVIDUALISTIC TO A CORPORATE INTELLECTUAL PROPERTY REGIME.}

Formally, there was little substantial change in the foundations of the patent system as described above, and yet the nature and content of the system changed radically. The focus of the system shifted from the individual, where the aim was to favour individual inventors, to the firm, which was now to be favoured as it became the central place of invention and innovation. To understand this shift, we need to analyse it from the perspective of institutional complementarities ${ }^{11}$. The nature of the patent system and its economic implications cannot be grasped fully by considering it in isolation, but only by taking into account the way this system is interrelated to other "institutional forms" that structure the economy. The first of these is, of course, the large corporation and, as we shall see, the formation of the wage-labour nexus and the structuring of the (product) markets; then, an aspect that was to become essential in the later, "post-Fordist" phase, the rise of finance-led capitalism and the structuring of the financial sphere.

From the end of the $19^{\text {th }}$ century, the business world became aware of the importance of technological knowledge as a strategic asset, mainly in the first science-based industries of the time: the electric and electronic and chemical industries. The conditions of appropriation and exploitation of this knowledge by firms therefore became essential. This led to two major problems: (1) how to obtain and maintain control over technological knowledge and skills, and more particularly that produced and possessed by employees; and (2) how to exploit the monopoly power provided by intellectual property, particularly in the face of the rise in antitrust policies in the US, following the 1890 Sherman Act.

\section{INTELLECTUAL PROPERTY AND THE LABOUR REGIME. THE STATUS OF THE EMPLOYEE-INVENTOR.}

In the US, the end of the $19^{\text {th }}$ and beginning of the $20^{\text {th }}$ centuries were marked by both a decline in individual, independent inventors (Lamoreaux and Sokoloff, 2005) ${ }^{12}$, and, as we have just recalled, the rise of the large corporation and the integration within the firm of invention and

\footnotetext{
${ }^{11}$ This viewpoint is developed by several institutionalist works, notably on the existence of different forms of capitalism (Amable, 2003; Aoki, 2001; Hall and Soskice, 2001).

${ }^{12}$ Changes in the patent system during the early $20^{\text {th }}$ century probably contributed to the decline in the application for patents by independent inventors. These reforms in the mode of operation of the patent office resulted in growing formalism, making the patent application process more complex and expensive, to the detriment of individual inventors (Nobel, 1977: 108).
} 
innovation activities. This found expression in the appearance of in-house $R \& D$, accompanied by the rationalisation and "routinization" of inventive and innovative activity, in what has been called the "innovation factory". More generally, the rise of the large, integrated corporation and new forms of industrial organisation, with the accompanying high degree of integration of employees within the firm, raised the problem of the appropriation and control, by the emerging managerial apparatus, of the knowledge and skills - the "human capital" - of the employees. The appropriation of skills and tacit knowledge became the subject of new forms of organisation, and particularly of Taylorist methods. The appropriation of more formalised technological knowledge (leading to patentable inventions) developed by the employees and of intellectual skills specific to the new categories of employees assigned to innovative activities, was partly achieved through changes in labour law, especially the law governing the ownership of patents. This is the aspect that particularly interests us here.

The appropriation of employees' patents by their firms gradually became established between the $19^{\text {th }}$ and $20^{\text {th }}$ centuries $^{13}$. When inventive activity is performed within the firm, the question arises of who will own the knowledge thus produced. The fact that patents could still only be legally registered by individuals had little influence on the question of who the subsequent owner would actually be. During most of the $19^{\text {th }}$ century, it appeared to go without saying that the inventor himself retained ownership of the patent, and thus all the rights over it, even if he was employed by a company. This was in keeping with the individualist conception of intellectual property rights, founded on the individual's natural right to the product of his work and personal abilities, and on a "heroic" view of the invention, specific to the pre-Fordist era, as a product of individual genius. And this was consistent with the predominance, described above, of individual, independent inventors. This upholding of the principle of an inventor's ownership of his invention, even when he was employed by a firm, was supported by the idea that ownership of the invention was governed solely by the legal principles of intellectual property rights ${ }^{14}$.

The situation was to change radically with the rise of corporate capitalism: appropriation of the invention by the company then became the rule. In the US, recognition of an employer's rights over his employees' patents emerged in two main stages, corresponding to two principles: that of the 'shop right' and that of the 'preinvention assignment agreement', which prevails today (Cherensky, 1993; Fisk, 1998; Merges, 1999).

During the first stage, which started in the mid- $19^{\text {th }}$ century, companies became able to acquire an exclusive license over their employees' inventions. To begin with, this possibility, later to become a right, was simply based on the idea that if an employee lets his employer use his

\footnotetext{
${ }^{13}$ For what follows, see mainly Fisk (1998).

${ }^{14}$ Between 1840 and 1880: "the inventor's status as an employee was irrelevant to ownership of inventions" (Fisk, 1998).
} 
patent, it can be considered that he has implicitly granted his employer a license. The company thus has a right to a license, on the basis of the employee's (implied) consent. Subsequently, at the end of the $19^{\text {th }}$ century, the employer's right was justified by the courts in quite a different fashion, by the fact that the employee had produced his invention within the context of working for his employer. This led to the "shop right" doctrine, emphasising the fact that the employer had borne the costs of the invention, by paying the employee's wages and providing his working tools. This gave the company the right to use an employee's invention, without paying him royalties but leaving him ownership of the patent (Fisk, 1998).

The coexistence of this movement, gradually affirming the "shop right" over employees' inventions, with the introduction and extension of Taylorism into the firm, cannot be overlooked. Several works have shown that with the Time and Motion Study, Taylorism acted as a gigantic process of expropriation of trade workers' skills, which were then parcelled out and redistributed to unskilled workers ${ }^{15}$. Indeed, until the arrival of Taylor, production skills were first and foremost the property and "monopoly" of skilled workers. This knowledge, mainly uncoded, was transmitted from one generation of workers to the next through the system of apprenticeship. Taylor's scientific management brought this situation to an end, by imposing modes of work division and organisation that were now decided by the management. The organisation of work was then claimed by employers' organisations as a "management right", in the face of longrunning protestations from skilled workers, - and their unions - claiming the right to choose what they deemed to be the most efficient operating modes. Thus, the struggle for the establishment of the "management right" and the "shop right" were closely connected. This confirms the strategic importance of confrontations over the content of the wage-labour nexus and its codification in the control and appropriation of skills, and indeed inventions, in manufacturing activities.

A major change then occurred when the firm became able to obtain ownership of the patent, and all the rights associated with that. From the end of the $19^{\text {th }}$ century, certain court rulings affirmed the employer's right to the ownership (and not simply the use) of an invention, from the moment that the employee had been recruited and paid to invent. But it was essentially after 1920 that a doctrine founding the ownership of inventions on the contract (of employment) became established. In 1933, a Supreme Court ruling presented it as an obvious principle that: "the respective rights and obligations of employer and employee, touching an invention conceived by the latter, spring from the contract of employment" $"$.

More generally, and looking beyond manufacturing activities, the content of employment contracts (and labour law) also shaped developments in the regime of patent ownership. As Fisk put it (1998: 1181): "Employers created, lawyers emphasized, and courts enforced express agreements that any employee's inventions would belong to the employer". The agreement giving ownership of an invention to the employer can be explicit, or considered to be implied.

\footnotetext{
15 On this point, see Taylor F. W. (1911) and 1971, Montgomery (1979), Aitkin (985), and our own works Coriat (1979), Coriat and Dosi (1998), Coriat (2000).

${ }^{16}$ United States vs. Dubilier Condenser Corp, 289 US 178, 187 (1933). Quoted by Fisk (1998).
} 
This constitutes the principle of the "preinvention assignment agreement": through his contract of employment, the employee undertakes to assign to his employer (the firm) all rights over future inventions created within the framework of his work, using resources provided by the employer. Today, we can consider that nearly all employees involved in scientific and technological work are subject to this type of agreement (Cherensky, 1993). And the contract often contains a 'trailing clause', by which the firm can claim ownership of any patent registered by one of its ex-employees during a certain period after the employee has left the firm (Nobel, 1977).

More precisely, today's legal system combines the right of the company to ownership of the invention, where the inventor has been "employed to invent" (the principle of the preinvention assignment agreement) with the right to a non-transferable license, where the inventor has not been expressly recruited for that purpose (the principle of "shop right"), mainly concerning employees working outside of R\&D (Merges, 1999).

This completed the formation of an intellectual property system founded no longer on the individual, but on the company. This fundamental transformation calls for two observations.

The first concerns the importance of the role played in this change by the formation of what the French regulationists call the wage-labour nexus. With the rise of corporate capitalism, a new system of relations between company and labour emerged, built on a certain status of labour: the wage-earning system. The latter is based both on the integration of workers into the firm, accompanied by the introduction of internal labour management and control systems (the TaylorFayol system), and on a specific legal framework: the contract of employment by which the company controls the activity of the worker and appropriates the results of that activity. The principle of the preinvention assignment agreement is one component of this new employment system, applying more particularly to a new category of worker, the "employee/inventor". It worth noting that this new status does away with any automatic system of reward for the inventive activity of the individual, which was supposed to be an essential justification of the patent system. The firm can define the mode of remuneration of the employee-inventor in an entirely discretionary manner, and the "reward" becomes a simple component of its pay policy. This once again illustrates the profound shift of the intellectual property regime towards a company-oriented system.

Our second observation concerns intellectual property itself. One consequence of the change we have just described is that the patent has become primarily a strategic corporate tool. The nature and economic consequences of the patent system are therefore determined by the way in which companies exploit it. In passing, we can add that the same is true for the copyright system. For companies, especially the large corporations, the patent system is first and foremost a tool for controlling markets. This aspect became established right at the beginning of the $20^{\text {th }}$ century, as demonstrated, for example ${ }^{17}$, by the strategies of Bell System and then AT\&T (created in 1900

\footnotetext{
${ }^{17}$ See Nobel (1977: 91-95)
} 
by the integration of Bell's different interests). Through an active policy of building up a patent portfolio, Bell gained domination over the whole telephone and communication sector. Another example is provided by the policy of General Electric, aiming, in the same way, to control the whole technology of the filament light bulb (among other domains) during the whole of the first half of the $20^{\text {th }}$ century. The development of "patent pools", initiated by companies, which accompanied the rise of corporate capitalism, is also and above all a tool of cartelization and for controlling an industry, through the construction of entry barriers ${ }^{18}$. This also radically changed the nature of the intellectual property system. And this raises another question: that of the relations between patent system and anti-monopoly regulations.

\section{INTELLECTUAL PROPERTY AND COMPETITION}

Prindle, a mechanical engineer and patent lawyer, influential at the beginning of the $20^{\text {th }}$ century, expressed the industrial world's view of patents very clearly and explicitly:

"Patents are the best and most effective means of controlling competition. They occasionally give absolute command of the market, enabling their owner to name price without regard to cost of production... patents are the only legal form of absolute monopoly., 19

As we have seen, the large corporations, especially in the new industries of the time, were soon putting Prindle's teaching into practice, making systematic use of patents as a means of controlling competition. By their very nature, patents offer their owners a (temporary) monopoly. But this went much further. Companies systematically exploited their possession of a portfolio of patents (constantly renewed) to obtain control over a market, a technology or an industry, either alone or with a group of companies (via a patent pooling agreement, for example ${ }^{20}$ ). As Machlup (1958) noted, different methods were used to prolong control of an industry beyond the patent's period of validity: using the invention before registering the patent, applying for successive patents for improvements on the invention, license agreements extending beyond the period of validity, registering broad-scope patents covering a whole industry ("umbrella patents") and so on. The different ways of using the patent system (sometimes combined with copyrights and trademarks) as a tool of industrial and commercial strategies would provide enough material for a particular study in their own right. These methods developed right from the early days of corporate capitalism.

\footnotetext{
${ }^{18}$ The radio patent pool, created in 1920 and bringing together companies like AT\&T, GE, RCA, United Fruit, American Marconi and Westinghouse, is a good example. See Noble (1977) and Danielian (1939).

${ }^{19}$ Edwin J. Prindle, "Patents as a Factor in a Manufacturing Business", Engineering Magazine, XXXI (September 1906), 809-10; XXXII (October 1906), 90. Quoted by Noble (1977: 89). Prindle added: “if a patent can't be secure on a product [...] it should be secured on process to make the product. [...] and if none of these ways is feasible, it should be considered whether or not the product cannot be tied up in some way with a patent on some other product, process or machine".

${ }^{20}$ See Machlup (1958: 11)
} 
Of course, this could not but raise questions about competition regulation. The room for manoeuvre allowed to firms and the functioning of the intellectual property system itself depend on anti-trust policy in particular and on state interventions in general, in the domain of compulsory licensing, for example.

The conditions of application of the Sherman Act varied widely over the course of the $20^{\text {th }}$ century (Kovacic and Shapiro, 2000). If we focus on the interrelation between intellectual property practises and anti-trust policy, and drawing on the work of Noble (1977) and Kovacic and Shapiro (2000), we can identify three different periods.

Broadly speaking, up until the beginning of the $20^{\text {th }}$ century, the Sherman Act was only loosely applied. This concerned intellectual property. It appears that during this period, patent holders suffered little constraint in the exploitation of their position of monopoly (Jaffe and Lerner, 2004: 96). Thus, in 1902, the US Supreme Court ruled that: "The general rule is absolute freedom in the use or sale of patent rights under the patent laws of the United States. The very object of these laws is monopoly"21.

Antitrust policy was even more lax during the period that followed, from 1915 on. The rulings of the Supreme Court reflected a relatively tolerant attitude towards practices of collusion and cooperation (Kovacic and Shapiro, 2000). This can be related to a comparative decline in the liberal credo, particularly after the Great Crash of 1929, and the "ascent of the 'associationalist' vision of business-government relations", linked notably to the experience of the First World War (Kovacic and Shapiro, 2000: 46). This helps to explain why we can observe, during this period, both private patent pools of an anti-competitive nature and patent pools encouraged by the state, often coupled with compulsory licenses, promoting cooperation between firms judged to be in the national interest. A good example of the first type is provided by the "radio patent pool agreements" of the 1920s, bringing together AT\&T, GE, RCA, United Fruit, American Marconi, and Westinghouse (Noble: 93). Patents pools of the second type were promoted by the Federal State, especially during the two World Wars, as a means of obliging firms to cooperate to accelerate the development of new weapons. Thus during World War I, for example, the Patent Board of the War and Navy Departments encouraged patent pools in the munitions and aircraft industries (Noble: 106).

The period that started in about 1940, and which continued up until the 1970s, is particularly interesting and important. This was the period during which antitrust policy, in application of the principles of the Sherman Act, was the most stringent. Practices of cartelization and the abuse of dominant position were punished much more severely, and merger and takeover operations were controlled more rigorously. This was bound to have repercussions for intellectual property. And indeed, the post-war period was characterised by a particular configuration, reflecting the

${ }^{21}$ E. Bennet \& Sons versus National Arrow Company, 186 U.S. 70, 91 (1902); quoted by Jaffe and Lerner, 2004: 96. 
importance of institutional complementarities, and essential for understanding the dynamics of innovation. It combined (Mowery and Rosenberg, 1998):

-- A strict antitrust policy, as we have just noted. This made it difficult for companies to take over firms in connected activities and technologies, leading to increased reliance on in-house $\mathrm{R} \& \mathrm{D}$, especially in the large corporations.

-- A relatively lax intellectual property regime. This was due partly to actions by the State, which often imposed compulsory licensing systems (as in the case of the transistor), but also to the behaviour of companies, subjected to the threats of the antitrust policy. As Mowery and Rosenberg (1998: 43) observed: "Liberal licensing and cross-licensing policies were by-products of antitrust litigation". This favoured the diffusion of technological knowledge and the emergence of new firms, particularly in the newly emerging high-tech industries (microelectronics, micro-computing and software). And we know the effect this situation had on the dynamics of innovation in the United States.

The economic and political changes that started to take shape in the 1970s, with the growing influence of the Chicago school, and which became firmly established in the 1980s, overturned this regime, sending it in an almost diametrically opposite direction. And this, coupled with the rise of finance-led capitalism, led to what we can consider to be a new intellectual property regime.

\section{THE 1980S: A NEW IPR REGIME AND THE ROLE OF FINANCE}

Here, as in the previous section, we must approach the changes in intellectual property from the perspective of the broader transformations in industrial structures. At the centre of these transformations lay the evolution of the business model, marked by what appears to be a relative decline in the "Chandlerian" firm, i.e. the large integrated firm, as the centre of the productive system $^{22}$. Firstly, there was a movement of vertical disintegration within the large corporations, tending to concentrate on a limited number of what were considered "strategic" activities. Secondly, there was strong growth in smaller companies, often highly specialised and not integrated, particularly in the high-tech, science-based industries. This includes start-ups, which became a mainspring in the dynamics of innovation. These companies are essentially - and sometimes exclusively - based on a certain capital of technological, or strictly scientific knowledge ${ }^{23}$.

To a certain extent, this development can be interpreted as the opposite to what had marked the phases of establishment and then hegemony of the Chandlerian firm. We witnessed a move towards greater externalization of the inventive activity. On a more general and fundamental

\footnotetext{
22 On this thesis, and the interrogations and debates it has provoked, see Lamoreaux et al. (2003, 2004), Langlois (2003, 2004) and Sabel and Zeitlin (2004), Gabrié and Weinstein (2007).

${ }^{23}$ See below, where this point is developed in more detail.
} 
level, there was also a decline in the role played by the "visible hand" of managers, to the benefit, according to certain authors, of the invisible hand of pure market relations (Langlois, 200,2004 ) or, according to others, of new inter-firm relations, long-term relations (Lamoreaux et al. 2003, 2004) or various forms of collaboration (Sabel and Zeitlin, 2004). This was expressed in an increase in transactions between companies, especially involving technologies, knowledge and skills. Another central feature of these transformations is essential to our purpose: in this new industrial configuration, the accumulation and allocation of capital or the choice of investments (including in R\&D), which, in the managerial capitalism of the Fordist phase, were carried out essential inside the large corporation, were now performed to a far greater extent by the financial markets and the agents working in them ${ }^{24}$.

This is the context within which we must situate the transformations in the intellectual property regime, if we are to understand how they took place. The period that started in the early 1970s marked a new evolution in the IP regime, with major changes. Three features characterised the new period:

- firstly, legal and jurisprudential changes led to a spectacular extension of the field of patentable objects and a strengthening of the rights granted to the owners of patents and other IPR;

- at the same time - although this process was most consequential in the United States, where it first emerged and took hold - substantial modifications were made in the regulation of financial markets. Operating in synergy with the changes in IP, these modifications provoked the formation of new institutional complementarities and unprecedented new characteristics in the practices surrounding the registration and exploitation of patents.

- finally, the type of IP regime that had hitherto only prevailed in the most developed countries was extended world-wide; this process of global harmonisation of IP laws reached its zenith in 1994 with the signing of the TRIPS agreement, marking the establishment of an international IP regime for the first time in history ${ }^{25}$.

One of the most important consequences of these changes has been an unparalleled leap forward in the commodification of knowledge. This is particularly due to two radically new phenomena: i) the emergence of firms specialised in basic research, a trend almost without precedent, as Rosenberg notes ${ }^{26}$; ii) the formation of a capital market for innovative firms. In relation with

\footnotetext{
${ }^{24}$ Which is partly explained by changes in management modes driven by the principle of shareholder value, central to the new principles of corporate governance. These changes resulted in a greater proportion of profits leaving the company and feeding into the financial circuits.

${ }^{25}$ This crucial aspect of the new period will not be examined here. For a recent explanation of how the TRIPS agreement marked the formation of a new international IP regime, see Orsi and Coriat (2006).

${ }^{26}$ Rosenberg observed that although it is not uncommon for large firms to have some in-house basic research, representing an element of the "absorptive capacity" which the firm needs to maintain its innovation capacity, a firm entirely specialised in basic research is a powerful "anomaly", as the conditions for its long-term viability cannot be guaranteed, given the 'public good' nature of knowledge (Rosenberg, 1990).
} 
these two major phenomena, this period thus marked the entry of finance as a key player, both as intermediary and as operator in the market for knowledge.

After describing the novelties marking the period since the 1980s, and how they characterise the emergence of a new IP regime, we identify some of the most important consequences of this new regime with regard to the development of the market for knowledge.

\section{A. THE DISTINGUISHING FEATURES OF THE NEW IP REGIME}

As noted above, the new regime became established through the combined effects of legal and jurisprudential changes. The most influential changes can be presented as follows ${ }^{27}$.

\section{LEGISLATIVE CHANGES}

One important change was the opening-up of the domain of patents (and of IPR in general) to new actors. In practice, these are universities and academic research laboratories, authorised by new legislation to register patents on the products of their research - even, quite remarkably, when the research has been publicly funded. This step was taken in 1980 with the passing of the Bayh-Dole Act. This major law (the pertinence of which is still fiercely debated), introduced a set of new, complementary measures. Firstly, it authorised the granting of patents on the results of publicly-funded research. Secondly, it provided for the possibility of selling exclusive licenses to private firms or of setting up "joint ventures" with them, with the objective of exploiting the knowledge concerned, either through direct trade (by selling it to third parties in the form of licenses), or by using the knowledge to develop marketable products. The rationale underlying these measures may be debatable, but its practical impact on the multiplication of the number of patents registered by university laboratories has certainly been spectacular, although these patents have been concentrated in a relatively small number of universities (Mazzoleni and Sampat, 2002; Mowery and al., 2004)

The importance of the change introduced by the Bayh-Dole Act cannot be over-emphasised. Apart from its direct significance, in abolishing a hitherto inviolable principle of public policy ${ }^{28}$,

27 The following paragraphs are drawn from elements already presented in some of our earlier articles (Coriat and Orsi 2002, Coriat and Orsi 2005). They develop and organize some of the basic findings first presented in Orsi (2001) Here, these elements are updated and placed in the perspective of our purpose in the current article.

${ }^{28}$ Up until the Bayh-Dole Act, public policy was organised around a relatively clear principle: public funding was destined for basic research (chiefly universities and public laboratories); most of the results were then made freely available to the actors involved in innovation. Private innovators, on the other hand, (relying on their own funds) were rewarded by the attribution of temporary monopolies through patents. This 'dichotomy' (subsidies for basic research, patents to reward private invention) ran largely along the lines of the theory of development presented by Arrow (1962), who saw it as a way of protecting collective wellbeing despite the granting of patents. By authorising patents on the results of publicly-funded research, the Bayh-Dole Act broke with this cardinal principle of "open science" from the Fordist period. In this sense, the law is in open contradiction to the principles of "wellbeing" that underpinned public policy in this domain for so long. 
the Bayh-Dole Act gave powerful impetus to the commodification of academic research. In many publicly-funded laboratories, the race to register patents became an organised activity. Thus, Technology Transfer Offices (TTOs) were set up, with the function of selling patents to third parties (often venture capital-financed firms) ${ }^{29}$ or to set up joint ventures with them to exploit the patents. Around the universities the most committed to basic research (and often the best-performing), there has been a spectacular boom in "spin-offs" from academic laboratories.

The trends initiated by the Bayh-Dole Act were further energised by another major legislative initiative, with the establishment by the US Congress of a specialised jurisdiction for IP. This is constituted by the Court of Appeals for the Federal Circuit (CAFC), now responsible for judging all cases of litigation involving IP.

This initiative turned out to have extremely important repercussions. By removing all powers of arbitration on IP from the traditional courts, often strongly marked by the anti-trust doctrine and openly opposed to the defence of patent-based monopolies, the introduction of the CAFC wide the door to the affirmation of "pro-patent" doctrines and rulings. These latter played a major role in the establishment and consolidation of the new IP regime. As one analyst recently observed, in a long article analysing the doctrines promoted by the CAFC: "The FC has steadily dismantled doctrines denying patents to such inventions as math algorithms, mental steps, printed matters and methods of doing business. Stripped of limiting principles, the subject matters for patenting in the US now appears as broad as the range of human experience" (Thomas J.R , 2006).

Supported by the new jurisprudential approach (often initiated or confirmed by the US Supreme Court itself), the modifications thus introduced affected every dimension of IP, always strengthening the nature and depth of the rights given to patent holders and the penalties and sanctions imposed on "imitators" 30 .

\section{JURISPRUDENTIAL CHANGES}

However, the major changes, those of such depth and range that they justify our speaking of a real change of regime, stem from the fact that in two key domains (corresponding to the great scientific and technological revolutions of the end of the $20^{\text {th }}$ century), patentability was opened up to objects that had been explicitly excluded. These were software and computer programmes on the one hand, and genes and living matter on the other.

It is obviously significant that these were the two key domains in which major technological discoveries and innovation took place during the 1980s. It really appears as if, in these new and emerging domains, the United States intended to use a new, much wider and stricter IP regime as a means to guarantee the industrial and commercial of their firms, by giving them exclusive

\footnotetext{
${ }^{29}$ This point is examined in more detail in the following subsection.

${ }^{30}$ For a more precise and detailed presentation of the changes that took place, see Coriat (2002), (Coriat and Orsi, 2002) and (Jaffe and Lerner 2004). For a very precise and accurate presentation of the changes in the field of genomics and biotech see Orsi (2001)
} 
rights to exploit not only their own inventions, as had been the custom, but also whole domains of discovery and basic research originating in US public laboratories ${ }^{31}$.

- In the domain of software and computer programmes, a series of rulings by the courts introduced a radically new situation. Firstly, software, which had been protected by copyright, could now be protected by patents. And these patents steadily spread outwards, ultimately covering even algorithms corresponding to the use of simultaneous equations. The essential point here is that this evolution has made it possible to patent elements of "generic" knowledge, widely used throughout the community of programmers and software designers, creating what many experts have described as a dangerous situation (see below). Lastly, in the 1990s, and particularly after the famous State Street vs. Signature Financial ruling (issued in 1998 by the CAFC), the evolution has continued with the extension of patentability to business models, i.e. automated processes relating to commercial methods or financial services ${ }^{32}$. The American firms that were often pioneers in these fields found themselves endowed with a forest of patents representing exclusive rights to exploit processes that had often been widely used by the computing community ${ }^{33}$.

- But it was in the domain of life sciences that the evolution was the most radical and the most influential. Here the breach was first opened by the famous Chakrabarty ruling, authorising General Electric to patent a genetically-modified micro-organism that could eat up oil slicks. This decision was made by the US Supreme Court, in the same year as the Bayh-Dole Act (1980) and after many years of legal battles and a long succession of decisions by different courts. It ultimately led to the patentability of living matter, including isolated elements of the human body such as genes and partial sequences of genes. So now, in the United States, as the US Patents and Trademark Office puts it: "Whoever discovers a gene may obtain a patent on that gene and on several possible applications, even if their use has not been demonstrated or one sole use has been disclosed" (USPTO, 2001). To date, more than 50,000 patents have been granted or applied for on sequences and partial sequences of genes.

Clearly, this opened the way to a veritable commodification of knowledge (Orsi, 2002; Orsi and Moatti, 2001). Whether this involves generic knowledge (e.g. the algorithms used as a basis for computer programmes) or, even more importantly, 'basic research' (the human genome), whole domains of knowledge that had previously belonged in the realm of open science have now been

\footnotetext{
${ }^{31}$ The reasons why such changes were implemented must be sought in the political economics of the period (the 1980s), during which the US suffered a sharp decline in its competitiveness. On this point, see our article Coriat and Orsi (2002) and the recent detailed study by Scherer (2006).

${ }^{32}$ For a detailed analysis of the evolution of IPR for software and its significance, see (, Liotard, 2002 and 2004, see also Dreyfus 2006).

33 Another consequence of this new situation was that many internet firms were promoted on the basis of the financial market's evaluation of the intangible assets represented by their patents and other IPR on computing methods (see below).
} 
swallowed up by exclusive appropriation, and have consequently become the objects of financial transaction on markets. ${ }^{34}$

And this has been exacerbated by a concurrent revolution in the regulation of financial markets, which, by entering into resonance and complementarity with these IP changes, has created totally new conditions for the development of the market for knowledge.

\section{B. NEW INSTITUTIONAL COMPLEMENTARITIES BETWEEN FINANCE AND IPR, AND A NEW BOOST TO THE COMMODIFICATION OF KNOWLEDGE}

The essential point here is that the transformation of knowledge into a commodity (in the form of marketable IPR promising future incomes) created the permissive conditions for financial capital to enter into the production of knowledge. From the moment that the new start-ups, often originating in university laboratories thanks to the Bayh-Dole Act, possessed marketable rights (via IPR), an opportunity opened up for the activity of financial capital.

Financial regulations were modified to facilitate and dynamize the entry of actors from the world of finance into the sphere of basic research. The most important move was a decision made by the NASD ${ }^{35}$ in 1984 to authorise the listing of loss-making firms, provided they possess a high level of "intangible" capital, constituted precisely by IPR. Thus, the regulation known as "Alternative 2" enabled this type of firm (loss-making, but with a stock of IPR) to be listed, no longer on the OTC ("over the counter"), an illiquid and unattractive market, but on the First Market of the National NASDAQ Market, the leading and most attractive NASDAQ market ${ }^{36}$.

\footnotetext{
${ }^{34}$ All the more so since the patents granted are often "broad scope", in other words they do not cover inventions of proven utility, but a wide range of potential future applications. By granting patents on basic knowledge itself (the input for future inventions), the American courts protect not only the inventions actually described and disclosed, but all the potential and virtual ones that might derive from use of the patented knowledge.

The conflict between Myriad Genetics and several European research organisations, including the Institut Curie, provides a good illustration of the consequences of the new doctrine. On the grounds that it owned patents on a breast cancer susceptibility gene (BRCA1), the American firm tried to impose exclusive use of its test kit, taking out lawsuits against a number of laboratories throughout the world that had developed and were using their own tests, even though the latter performed better in terms of cost-effectiveness. An analysis of this case and its significance are presented in Orsi and Coriat (2005)

35 National Association of Securities Dealers: this is the body responsible for the regulation and security of transactions on the NASDAQ, under the authority of the SEC (Security Exchange Commission).

${ }^{36}$ For a detailed presentation of the conditions under which this "Alternative 2 " emerged on the NASDAQ, and its significance, see Orsi (2001). On the same theme, see also Coriat, Orsi and Weinstein, (2003).
} 
Other legislative and regulatory changes in the financial domain then played a key role in ensuring financial resources for this market in loss-making but high-potential innovative firms, which often have IPR as their essential assets. In particular, the "prudent man" legislation imposing certain constraints on pension funds was modified to allow them to invest part of their funds in high-risk bonds and assets, something that was previously forbidden to them. In this way, some of the huge liquidities concentrated in pension funds, which boomed during this period, particularly after introduction of the $401 \mathrm{k}$ legislation, were used by the financial markets to promote hundreds of new firms which, although loss-making, were considered "high potential", because of their intangible assets (see S. Montagne, 2006, for an exhaustive analysis of the changes in the functioning of pension funds in the wake of legislative and regulatory changes).

\section{COMPLEMENTARITY BETWEEN FINANCIAL MARKETS AND IPR}

This resulted in the formation, originating in the United States, of a singular new "institutional complementarity" between IP law on the one side and financial market regulation on the other.

This new complementarity functions according to the following protocols:

- the extension of patentability to the results of publicly-funded research, completed by the CAFC rulings that authorised patents on genes and more generally on the products of basic research, previously made freely available in the public domain, provided university laboratories with unprecedented opportunities to commodify their activities. When they are not purely and simply sold in the form of exclusive licenses, the patents owned by these laboratories are used as the basis for the creation of specific companies seeking to establish the so-called "proof of concept", within establishments still operating on the products of basic research but oriented towards the potential applications of new discoveries;

- the possibilities given to pension and other mutual funds to invest in high-risk activities gave a powerful boost to the supply of venture capital, while at the same time the new NASDAQ regulations opened up new exit possibilities for firms financed by venture capitalists; venture capital firms naturally turned in mass towards these new "companies" constituted by research laboratories endowed with high levels of intangible capital, in the form of patents and other IPR which could now be valorized on the markets.

From the point of view of commodification, the effects of these complementarities were spectacular. The combination of a new IPR regime with the NASDAQ "Alternative 2" regulation allowing non-profitable firms, whose assets may be in the form of IPR, to be listed on the stock market, allowed the launch of firms of a very particular type, built on totally new business models $^{37}$.

\footnotetext{
${ }^{37}$ A detailed analysis of the formation of this complementarity and the way it served as a support to the creation of the main genomic firms in the US is presented in Orsi, 2001.
} 
These complementarities resulted in a series of novelties that were to stimulate the phenomena of the commodification of knowledge by providing them with new, largely unprecedented resources and supports.

\section{A NEW STIMULUS AND NEW SUPPORTS FOR THE COMMODIFICATION OF KNOWLEDGE}

One of the most radical novelties we have witnessed consists in the fact that it is no longer only knowledge that is commodified (through the sale of licenses and exploitation rights of various kinds), but the complex entities constituted by the new firms specialised in research. Alongside a market in licenses, a market has also formed in firms specialised in the production of knowledge.

There are two main aspects to this phenomenon.

- Firstly, we have seen the emergence of firms specialised in research. As Rosenberg (1990) noted, this is a powerful "anomaly". For the first time in history, a series of new firms were created and launched in market activities, with basic research as their central activity. This was made possible because the new regime, by authorising patents on basic research, also enabled the sale of research finding-related IPRs, which became the primary commercial activity of this new type of firm. One striking particularity of these firms is that most of them are built around "star scientists" (Zucker and Darby, 1996). As Darby et al. (1999) observed, the presence of renowned scientists in their founding teams (and amongst their shareholders) appears to have been an essential precondition for enhancing the quality credibility of their commercial products (in fact scientific discoveries covered by patents). ${ }^{38}$ The inclusion of scientists among the founders and shareholders of these firms is an important point. As in the previous phases (described above), this new change in IP regime has been accompanied by innovations and novelties in the codifications of the employment relation. Most of the scientists involved in setting up joint ventures are not simple "employees"; neither are they "hired to invent", as in the past. The novelty is that they are veritable associated shareholders owning a significant percentage of the share capital of the firm. The aim is both to win the confidence of investors when the firm goes public, and to provide an efficient incentive; the researchers-scientists will only be rewarded if - and to the extent that - their activity leads to the marketing of discoveries.

- Secondly, a "market" has grown up, whose main activity is the evaluation (notably in relation to IPOs) of these firms that lack marketable products and profitable activities, but that are considered "high potential" because of the patents they possess. This market is organised around a series of intermediaries and following its own specific protocols. "Analysts" specialised in patent evaluation appeared and were recruited by the big financial services firms who supply investors with

\footnotetext{
${ }^{38}$ Zucker and Darby (1996) find a positive correlation between the number of stars and the market value of high-tech firms. There are two possible interpretations of this observation: (i) the probability of successful innovation really is related to the number of star scientists, or (ii) the investors believe that the probability of successful innovation is related to the number of star scientists.
} 
information. These evaluations are quoted in IPO prospectuses, which use the presence of renowned scientists in the capital of the firm as a means of establishing the credibility of the public offering. However, although the formation of this market had significant consequences, endowing the financial community with an unprecedented power of evaluation with regard to the quality of discoveries, there was nothing to guarantee the validity of the judgements and choices made. The extraordinary overvaluations resulting from these protocols in the case of certain biotech firms - of a far greater scale than the over-valuations to be observed in the general market of firms listed on the NASDAQ as a whole $^{39}$ - provide a spectacular illustration of the excesses to which this can lead.

Beside these fundamental novelties, typical of the modern period, the new IP regime has played a highly paradoxical role as regards the market for knowledge as it had formed during previous periods. The paradox lies in the fact that although the market has been considerably enlarged and extended, it is a very imperfect market, of highly questionable efficiency.

One of the particularities of this new market is that it deals with very "upstream" knowledge, as it concerns both basic knowledge in the domains of genomics and biotechnologies and generic knowledge in the field of computing. This extension goes hand in hand with the fact that the number and variety of actors operating in this market has greatly increased. Alongside universities and public laboratories, specialist intermediaries have appeared both in the domain of IP (the TTOs) and in finance. The finance industry has become more complex, and venture capital firms have seen the arrival and growing importance of experts in the evaluation of the intangible assets represented by IPR. All this has taken place in a considerably larger market, as the strong growth in the number of patents has greatly increased the volume of the market's chief commodity.

However, the highly specific characteristics of these markets are largely due to a number of different imperfections. Firstly, the low quality of patents granted has given rise to a sharp increase in litigation costs. And even when open conflict is not declared, innovators are confronted with a situation of great uncertainty about what has and has not been patented. Navigating through the "patent thicket" - as Shapiro (2001) calls it- has become an undertaking that many firms, particularly in the sector of ICT, give up on, leaving themselves exposed to risks against which they seek to protect themselves, wherever possible, by forming "patents pools" with their partners or even with their competitors. In the biotechnologies, the exclusivity granted over certain gene sequences or research tools threatens to create an anticommons phenomenon Heller and Eisenberg, 1998) that will be highly prejudicial to the development of innovation.

\footnotetext{
39 And greater even than those observed during the exceptional period of the formation of the dotcom bubble that exploded in 2001.
} 


\section{TO CONCLUDE}

Our investigations have brought several points to light.

Firstly, the wide historical variability in the nature and content of intellectual property rights. Over the period examined, we have identified no less than three very distinctive regimes. The current "fetichization" of IP thus appears as a recent phenomenon with no historical antecedents. Furthermore, there is no real continuity, either in terms of the rights-holder or the depth and extension of the rights granted.

Another lesson is that the successive systems of property rights have only been able to take root and become established by entering into tensions and complementarities with other systems regulatory regimes and systems of laws, governing other dimensions of economic and particularly corporate activity. Labour law, or more broadly the wage-labour nexus on one side and competition law on the other, have often played a decisive role (often through their own transformations) in defining the nature and scope of the IP rights determined by law or jurisprudence.

Finally, if we focus on the most recent trend, starting in the 1980s, it is clear that although the shift towards commodification of knowledge - notably due to the rise of finance-led capitalism is a striking and important phenomenon, there is nothing to guarantee the long-term sustainability of the new regime. The new "markets" for knowledge that have recently emerged are highly imperfect, raising many obstacles to the circulation of knowledge.

One last point deserves particular emphasis. These imperfections and obstacles that have emerged with the dissolution of the "open-science" regime have given rise to a multiform reaction aiming to re-establish some of the conditions that prevailed before or to create, within the new context, conditions favourable to an easier circulation of scientific and technological information. Thus the open-source movement - which first arose in the field of software - is now spreading to the domain of biotechnology. At the same time, a number of different initiatives have been taken to protect or even extend the public domain. Finally, under the name of "creative commons", we can observe initiatives taken in the literary and artistic domains to escape from the restrictions of exclusive property that recent extensions in copyright law have sought to impose.

At the very least, these initiatives reveal the difficulties that the new regime has in becoming established. They may well be the expression of a new mutation that is still in search of its path and expression. 


\section{REFERENCES}

Aitken, H. G. J., (1985) Scientific Management in Action : Taylorism at Watertown Arsenal 1908-1915, Princeton University Press

Aoki, M. (2001), Towards a Comparative Institutional Analysis, The MIT Press. Cambridge, Massachusetts.

Amable, B. (2003), The Diversity of Modern Capitalism, Oxford University Press, Oxford, New York.

Cooper Dreyfus R. (2006) "State Street or Easy Street : is Patenting Business Methods Good For Business?" in Hansen H. (ed) US intellectual Property Law and Policy, Queen Mary Studies in Intellectual Property, Edward Elgar (pp. 1-38)

Coriat B. (1979), L'Atelier et le Chronomètre, ed Bourgois, Paris, paperback ed 1994

Coriat, B. (2000) "Competencies, Routines and Command in the Japanese Production System, in Giovanni Dosi, Sidney Winter and Richard Nelson (eds) : Competencies, Routines and Dynamic Capabilities, Oxford University Press.

Coriat B. (2002) «Le Nouveau Régime Américain de la Propriété Intellectuelle : Contours et Caractéristiques clés», Revue d'Economie Industrielle, $\mathrm{n}^{\circ} 99,2^{\mathrm{ieme}}$ semestre

Coriat B., Dosi G, (1998) "Learning how to Govern and learning how to solve problems : On the co-evolution of competences, conflicts and organizational routines, in Chandler A.D Jr, Hagtröm P. and Sölvell Ö : The Dynamic Firm - The role of Technology, Strategy, Organization and Regions, Oxford University Press, paperback ed 1999

Coriat, B, Orsi, F. (2005), « Propriété intellectuelle, marches financiers et promotion des firmes innovantes. Un retour sur la «nouvelle économie » dans Frison-Roche M-A et Abello A (eds) Droit et économie de la propriété intellectuelle, L.G.D.J.

Coriat B. and Orsi, F. (2002) «Establishing a New Regime of Intellectual Property Rights in the United States, Origins, Content Problems », Research Policy, n³1, Nov-Dec (pp 14911507)

Coriat, B. Orsi, F and Weinstein, O. (2003) "Does Biotech reflect a New Science-Based Innovation Regime ?", Industry and Innovation, Vol. 10, (pp.231-253).

Chandler, D. Jr, (1992) 'Organizational Capabilities and the Economic History of the Industrial Enterprise', Journal of Economic Perspectives, 6 (3): 79-100.

Cherensky, S. (1993), “A Penny for Their Thoughts: Employee-Inventors, Preinvention Assignment Agreements, Property, and Personhood”, California Law Review, Vol. 81, No. 2. (March), pp. 595-669

Dasgupta, P. and David, P.A. (1994) "Toward a New Economics of Science". Research Policy, 23, 487-521. 

York.

Danielian, N. R. (1939), AT\&T: The Story of Industrial Conquest. Vanguard Press, New

Fisk, C. L. (1998). "Removing the 'Fuel of Interest' from the 'Fire of Genius': Law and the Employee-Inventor, 1830-1930", The University of Chicago Law Review, Vol. 65, No. 4. (Autumn), pp. 1127-1198.

Gabrié, H. and Weinstein O. (2007), «L' entreprise du $21^{\text {ème }}$ siècle : vers une firme postchandlerienne? », in Rencontres économiques d'Aix-en-Provence, Le Cercle des économistes.

Hatchuel, A. (2004), "Rethinking management. A historical look at firms as institutional innovations", Issues in Regulation Theory, $\mathrm{n}^{\circ} 47$, January.

Hall, P. A. and D. Soskice (2001), Varieties of Capitalism, Oxford University Press, Oxford, New York.

Jaffe, A. B. and J. Lerner, (2004), Innovation and Its discontents, Princeton University Press, Princeton and Oxford.

Hansen H. (ed) (2006) US intellectual Property Law and Policy, Queen Mary Studies in Intellectual Property, Edward Elgar

Heller, M and Eisenberg, R. (1998), "Can Patent Deter Innovation? The Anticommons Tragedy in Biomedical Research", Science, Vol. 280; pp. 698-701.

Khan, B. Z., and K. L. Sokoloff (2001), "The Early Development of Intellectual Property Institutions in the United States", Journal of Economic Perspectives, Volume 15, Number 3, Summer 2001, pp. 233-246.

Kovacic, W. E. and C. Shapiro, (2000), "Antitrust Policy: A Century of Economic and Legal Thinking”, Journal of Economic Perspectives, Volume 14, Number 1 (Winter) 43-60.

Kutznets, S. (1966), Modern Economic Growth, Yale University Press, New Haven, Conn.

Lamoreaux, N., D. Raff and P. Temin (2003), « Beyond Markets and Hierarchies: Toward a New Synthesis of American Business History », American Historical Review, $\mathrm{N}^{\circ} 108$

Lamoreaux, N., D. Raff and P. Temin (2004), «Against Whig History », Enterprise and Society, N³.

Lamoreaux, N. R. and K. L. Sokoloff (1999) "Inventors, Firms, and the Market for Technology in the Late Nineteenth and Early Twentieth Centuries," in Naomi R. Lamoreaux, Daniel M. G. Raff, and Peter Temin, eds., Learning by doing in markets, firms, and countries. Chicago: University of Chicago Press, pp. 19-60.

Lamoreaux N. R. and K. L. Sokoloff, (2001) "Market Trade in Patents and the Rise of a Class of Specialized Inventors in the19th-Century United States", American Economic Review, vol.91, n², may, pp. 39-44.

Lamoreaux, N. R. and K. L. Sokoloff, (2002), "Intermediaries in the U.S. Market for Technology, 1870-1920”, Working Paper 9017, June, NBER Working Paper Series. 
Lamoreaux, N. R. and K. L. Sokoloff, (2005), "The Decline of the Independent Inventor: A Schumpterian Story", NBER Working Paper No. 11654, September. http://www.nber.org/papers/w11654.

Langlois, R. (2003), «The Vanishing Hand: The Changing Dynamics of Industrial Capitalism », Industrial and Corporate Change $\mathrm{N}^{\circ} 2$.

Langlois, R. (2004), «Chandler in a Larger Frame: Market, Transaction Costs and Organizational Form in History », Enterprise and Society, N⒌

Liotard, I. (2002) "La Brevetabilité des logiciels : les étapes clés de l'évolution jurisprudentielle aux Etats Unis", Revue d'Economie Industrielle, $n^{\circ} 99,2^{\text {ième }}$ trimestre.

Liotard, I. (2004) "Les brevets sur les méthodes commerciales : état de lieux et

Machlup, F. (1958), An economic Review of the Patent System, Study of the subcommittee on patents, trademarks and copyrights of the Committee on the judiciary United Sates Senate. Study $\mathrm{N}^{\circ} 15$. United States government printing office, Washington.

Machlup, F and E. Penrose (1950), "The Patent Controversy in the Nineteenth Century", The Journal of Economic History, Vol. 10, n¹, May, pp. 1-29.

Mazzoleni, R. and Sampat, B-N., (2002), "University Patenting: An assessment of the Causes and Consequences of Recent Changes in Strategies and Practices", Revue d'Economie Industrielle, Special Issue, 2002, pp.233-248.

Merges, R. P. (1999), "The Law and Economics of Employee Inventions", Harvard Journal of Law \& Technology, Volume 13, Number 1, Fall.

Merton, R. K. (1973), The Sociology of Science: Theoretical and Empirical Investigations. N.W. Storer, ed. Chicago: University of Chicago Press.

Meyers, S. (1992) The Five Dollars Day. Princeton University Presse

Montgomery, D.(1993) Workers Control in America. Cambridge University Press

Mowery D. C., R. R. Nelson, B. N. Sampat, and A. A. Ziedonis (2004), Ivory Tower and Industrial Innovation. University-Industry Technology Transfer Before and After the Bayh-Dole Act. Stanford University Press.

Mowery, D. C. and N. Rosenberg, (1998), Paths of innovation, Cambridge University Press, Cambridge ans new York.

Noble, D. F. (1977), America by Design. Science, Technology and the rise of Corporate Capitalism. Alfred A. Knopf, New York.

Orsi, F. and Coriat B., (2005) "Are Strong Patents beneficial to Innovative Activities Lessons from genetic testing for breast cancer controversies, Industrial and Corporate Change, vol 14, n 6 (pp. 1205-1221),

Orsi, F., Coriat B. (2006), "The New Role and Status of Intellectual Property Rights in Contemporary Capitalism", Competition and Change, Vol.10, (2) p. 162-179. 
Orsi, F (2001) «Droits de propriété intellectuelle et marchés financiers dans les nouvelles relations Science/Industrie », $\mathrm{PhD}$ dissertation, Université de la Méditerranée, Marseille.

Rosenberg, N. (1990) "Why do firms do basic research (with their own money)?" Research Policy 19, pp. 165-174

Sable, C. and J. Zeitlin (2004), "Neither Modularity nor Relational Contracting: InterFirm Collaboration in the New Economy" Enterprise \& Society, Vol. 5 No. 3.

Shapiro, C. (2001), "Navigating the Patent Thicket: Cross Licenses, Patent Pools, and Standard-Setting", NBER Conference on Innovation Policy and the Economy.

Sherer F. M. (2006), "The Political Economy of Patent Policy Reform in the United States”, DIME Working Papers on Intellectual Property Rights, n²6.

Taylor, F. W., (1911) The Principles of Scientific Management, Norton Library, Harper and Row, $1^{\text {st }}$ ed 1911, paperback ed 1967

Taylor, F. W., (1971) "Testimony Before the Special Committee, House of Representatives, in F. W. Taylor, Scientific Management, Greenwood, new York

Thomas J. R., (2006) "Discharging the Canons of Claim Construction : Exercises in interpretation at the United States Court of Appeals for the Federal Circuit" in Hansen H. (ed) US intellectual Property Law and Policy, Queen Mary Studies in Intellectual Property, Edward Elgar (pp. 134-163)

Winter, S. G. (1987), "Knowledge and Competence as Strategic Assets” . In D. J. Teece (Ed.). The competitive Challenge. Ballinger Publishing Company, Cambridge, Massachusett.

Zorina Khan, B. (1995) "Property Rights and Patent Litigation in Early Nineteenth-Century America," Journal of Economic History, March 1995, 55(1), pp. 58-97

Zucker, L.G. and Darby, R. (1996), "Star Scientists and Institutional Transformation : Patterns of Invention and Innovation in the Formation of US. Biotechnology Industry", Proceedings of the National Academy of Science, 93(23), pp. 709-716. 